\title{
Technological Mediation and Power: Postphenomenology, Critical Theory, and Autonomist Marxism
}

\author{
Mithun Bantwal Rao • Joost Jongerden • \\ Pieter Lemmens • Guido Ruivenkamp
}

Received: 1 April 2014 / Accepted: 22 January 2015 /Published online: 13 February 2015

C The Author(s) 2015. This article is published with open access at Springerlink.com

\begin{abstract}
This article focuses on the power of technological mediation from the point of view of autonomist Marxism (Hardt, Negri, Virno, Berardi, Lazzarrato). The first part of the article discusses the theories developed on technological mediation in postphenomenology (Ihde, Verbeek) and critical theory of technology (Feenberg) with regard to their respective power perspectives and ways of coping with relations of power embedded in technical artifacts and systems. Rather than focusing on the clashes between the hermeneutic postphenomenological approach and the dialectics of critical theory, it is argued that in both the category of resistance amidst power-relations is at least similar in one regard: resistance to the power of technology is conceptualized as a reactive force. The second part of the article reads technological mediation through the lens of the antagonistic power-perspective on class struggle developed in autonomist Marxism. The outline of a provisional autonomist philosophy of technology is developed using Foucauldian dispositifs of biopower in contrast to the hermeneutic and dialectical approach. It is thus argued that resistance should here be understood in terms of practice that subverts the technically mediated circuit of production itself.
\end{abstract}

Keywords Autonomist Marxism · Critical theory of technology · Foucault . Postphenomenology Technological mediation

\footnotetext{
M. Bantwal Rao $(\bowtie) \cdot J$. Jongerden $\cdot$ G. Ruivenkamp

Sociology and Anthropology of Development, Wageningen University, Hollandseweg 1, Wageningen $6706 \mathrm{KN}$, The Netherlands

e-mail: mithun.bantwalrao@wur.nl

P. Lemmens

Department of Philosophy and Science Studies, Faculty of Science, Radboud University Nijmegen, Nijmegen, The Netherlands

G. Ruivenkamp

University for Humanistic Studies, Utrecht, The Netherlands
} 


\section{Introduction}

How can we conceptualize resistance in our technologically mediated world? Perhaps the word resistance rings alarm bells with contemporary philosophers of technology, especially with those who have stressed the essentially interwoven character of man and technology. For does not resistance imply a retreat into neo-Luddism, a denial of the fact that our lives are so saturated by technological mediation, that any such retreat is nothing more than false nostalgia, a longing in vain for an authentic state of being that our modern technological world has diluted? In the following, we will deal with resistance, but not of the neo-Luddite sort. We deal with resistance in view of the power of capitalism.

Marx was the first to extensively theorize the relations between power, capitalism, and technology, and following up on (a certain tendency in) his thought that technology is not socially neutral, such present day philosophers as Andrew Feenberg (1991, 2002), Graeme Kirkpatrick (2008), and Douglas Kellner (1992) have devised a neoMarxist critical theory of technology revolving mainly around the issue of how the social and the technical intertwine. But not everyone is a Marxist. Under the label postphenomenology, Don Ihde (1990), Don Ihde and Evan Selinger (2003), and PeterPaul Verbeek (2005) have focused on the transformative dimension of technical artifacts on human experience, their efforts revolving around the concepts of technical mediation and relational ontology. Among their claims has been the discrediting of Marxist approaches, charging the latter with a lingering but inherent technophobia (Verbeek 2013). On their part, critical theorists have taxed postphenomenology with a disregard for the political implications of technology, or more generally, for not coming to terms with the power of technology (Feenberg 2009). This clash between these dominant currents in philosophy of technology has sparked some debate between scholars from these schools, leading to concessions on both sides. Feenberg's recent work, for example, explicitly deals with phenomenology and social constructivism, and has a markedly less distinct Marxist flavor (2010). Verbeek (2011) has addressed the normative lack of postphenomenology by dealing with the power of technology within liberal democracies. This debate is by its very nature political, and thus encompasses such themes as democratization, power, resistance, and so on. Given their differing methodological, epistemological, and ontological frameworks, it comes as no surprise that postphenomenologists have come up with different interpretations of filling in these themes than critical theorist have. In this article, we will bring a third voice into this debate, the voice of autonomist Marxism, associated in the present day with such authors as Antonio Negri, Franco Berardi, Maurizio Lazzarato, and Nick DyerWitheford but not frequently associated with the discourse on technological mediation. We argue that autonomist Marxism offers an alternative understanding of how to conceptualize the power of technology: instead of understanding the representative political realm as the arena of struggle, resistance is placed back in the productive circuit, the locus originalis of the power of antagonism. Another great commentator of capitalism, Michel Foucault, once remarked that "[w]here there is power, there is resistance" (1978, p. 95), but giving meaning to this truism is less trivial than it may seem. In the next section, we will review how this has been done in postphenomenology and critical theory of technology, focusing on the works of the figureheads Verbeek (who gives a Foucauldian reading) and Feenberg (who bases his 
view on Marcuse). Instead of understanding their approaches as radically opposed, it is argued that their views are largely congenial to each other in their pragmatism for construing the good life. In particular, we take issue with the claim made in postphenomenology that Marxist approaches cannot account for the technical constitution of human subjectivity. Thereafter, we propose an alternative way of understanding power/resistance by drawing on the incorporation of Foucault's work within the autonomist tradition, focusing on the Marxist interpretation given to his notion of biopower. The result of this will be a provisional outline of an autonomist view on technology: the mediation of the class struggle.

\section{The Power of Technological Mediation}

The triad of capitalism, technology, and power is to be questioned with regard to mediation. While capitalism may be uncontroversially defined as a politico-economic system based on property, the privatization of the means of production, surplus value extraction, capital accumulation, and the social relations that go with it, and technology trivially characterized as any man-made utensil or machine to serve some kind of need or purpose, the notion of power is much more ambiguous. To be sure, in the context of societal matters, power is unequivocally linked to politics, to the field in which decisions relating to the collective are contested, organized, and settled. In particular, power relations, the exercise of power by one social agent (institution, group, class, etc.) over another, operate as an area of struggle and become an issue of debate assigned to the political realm.

According to Brey (2007), following and amending Fay's (1987) general categorization of five systematic power relations, technology can enhance and transform the manner in which coercion, seduction, force, manipulation, and leadership are exercised. For example, a country possessing nuclear weapons has strong coercive power over others lacking such weapons, and it is well known how advertisements are employed in various media to seduce their users into consumption. Latour (1992) has drawn attention to how artifacts can exhibit force by triggering behavioral responses from their users, while technology can have a manipulate twist when we think of malware and spyware secretly nesting itself in PCs, and a policeman's uniform confers and strengthens the authority of its wearer over the public.

In the following, we do not aim to analyze the intertwinement of power and technology in its various incarnations and facets, but focus, rather, on the entanglement of power and technological mediation in view of capitalist power relations. In so doing, we will defend a particular conceptualization of power: largely, we follow Michel Foucault's trajectory of the study of power through processes of subjectification, to wit, "technologies of power," which "determine the conduct of individuals and submit them to certain ends or domination, [through] an objectivizing of the subject" (Foucault 1997a, p. 225), and more precisely, the manner this conceptualization of power has been elaborated by the autonomist Marxists. While generally considered a historian and philosopher of discourse, attention has been drawn to the relevance of Foucault's work on power for philosophy of technology, Discipline and Punish in particular (Dorrestijn 2012; Gerrie 2003; Sawicki 2003; Verbeek 2011). 
In Discipline and Punish, we recall, Foucault sketches an outline of Western Europe modernizing in tandem with the waning of "sovereign power" localizable in, and possessed by, the figure of the King, and the waxing of "disciplinary power", that power which not so much represses as produces the subject, rendering its body ever more docile and utile. ${ }^{1}$ Methodologically, Foucault undertakes this endeavor to dislodge the study of power, to move it away from the juridico-discursive model (Foucault 1978 , p. 90) and toward one that studies it in its positive, material, and technological determinations:

[I]n short, this power is exercised rather than possessed; it is not the 'privilege', acquired or preserved, of the dominant class, but the overall effect of its strategic positions - an effect that is manifested and sometimes extended by the position of those who are dominated. Furthermore, this power is not exercised simply as an obligation or a prohibition on those who 'do not have it'; it invests them, is transmitted by them and through them. (Foucault 1977, p. 26f.)

In this conception of power, the subject has a dual character: it both constitutes and is constituted by relations of power. Historically, Foucault locates the emergence of such power in the eighteenth century and sees it as being exercised in disciplinary institutions such as hospitals, prisons, schools, and factories, which, as propagators of "knowledge-power," produce norms about what counts as normal and what counts as abnormal, as healthy and as ill, and so forth. Foucault's best-known example of how disciplinary power can be embedded in artifacts is Bentham's circular prison, the Panopticon, in which prisoners do not know whether they are being observed or not. While Foucault generally reserves the word "technology" for reference to manners in which subjects are governed, this example can be taken as paradigmatic for a study of how power can constitute subjects in a material fashion (Feenberg 2002, p. 68). In his later work on self-mastery and ethics as self-conduct in the texts of Greek, Roman, and early Christian authors, Foucault $(1990,1992)$ would shift his attention away from studying how subjects are constituted as "objects" of power, and concentrate on how, amidst relations of power, subjects can also constitute themselves as subjects, through so-called "technologies of the self" (Foucault 1997a), and how such "technologies of the self" may intertwine with "technologies of domination".

To be sure, in the Foucauldian usage of the word, power does not necessarily bear the pejorative connotation it may have in a more colloquial idiom. With reference to Habermas' ideal communicative speech community, Foucault remarks that "I do not think that a society can exist without power relations, if by that one means the strategies by which individuals try to direct and control the conduct of others" (Foucault 1997b, p. 298). It is power's perversion, for which Foucault usually reserves the word "domination," that we need to be wary of, when one social group oppresses another, leaving no room for maneuver. Nevertheless, even if power is not necessarily pejorative, it is always political. For example, the political project that was industrial

\footnotetext{
${ }^{1}$ Deleuze (1995) has argued that Discipline and Punish does not describe the rise of disciplinary societies, but their decline. Written on the threshold of the rise of global neo-liberalism, Foucault's analyses bear more relevance to social regulation in Fordist factory societies than to those of current post-Fordism. In autonomist Marxism, this interpretation is expanded.
} 
capitalism deployed the power-techniques developed in the madhouse and the prison, inserting them throughout the social field in schools, hospitals, and, of course, the factory, the assembly line being the most pregnant instantiation of it (Foucault 2003, pp. 33, 36; see also Fraser 2003; Hardt and Negri 2000, p. 23). ${ }^{2}$

In the 1980s, Foucault's work sparked controversy and led to some heated debate as to whether his gloomy narrative of modernizing Europe placed too much emphasis on its negative, dominating aspects, and too little on its emancipatory ones (Fraser 1985), with Habermas (1981) labeling Foucault "a young conservative" adhering to a "cryptonormativist" approach. Less focusing on his conception of modernity, and more so on his theory of power, Lukes (2005) has argued that Foucault's endeavors are interesting and provocative, but do not shed any fundamental new light on what power is, and contain wildly exaggerated statements. ${ }^{3}$ Foucault's contention that power is everywhere and constitutes subjects, amounts to no more than the sociological commonplace that any notion of subjectivity is inseparable from socialization in a given culture (in the family, at school, at work, etc.), and that subjects internalize and exhibit cultural roles and practices as naturally given (Lukes 2005: 97). Moreover, the claim that power is both productive and oppressive is tantamount to saying that power solicits compliance from agents subject to it, i.e., power is seductive (Ibid. 98). Third, when Foucault describes such a phenomenon as the Panopticon, he is not describing power in its empirical workings, but an ideal type of a specific power-technique, carcerality in this case. Finally, and most notoriously, it has been suggested that Foucault presents power as an "iron cage" which we cannot, or even should try, to escape from (Allen 1999).

Although Lukes is correct that Foucault has a penchant for the hyperbole, his "sociological" critique also misfires by missing the philosophical import of Foucault's power theory. First, Foucault always stressed that power relations are unstable and emerge through the struggle of forces in which "resistance is never in a position of exteriority in relation to power" (1978, p. 95). But more fundamentally, Lukes sociological reading does not fully appreciate the philosophical import of Foucault, or more precisely his blend of Kantianism and Nietzscheanism; in a sense Foucault analyses a regime of power to understand how such a mutation as that from sovereign to disciplinary power forms as it were the "condition of possibility" for such a regime as capitalism. To claim that power constitutes subjects is equivalent to saying that we cannot "simply" rid ourselves of it, but that any engagement with power is an engagement with "oneself". Last, Agamben (2009a) has drawn attention to the use of "ideal-types" in Foucault's work: these "ideal-types" function not so much as abstractions of a reality which never existed in the first place (as Lukes has it), but rather as paradigms: just as Wittgenstein discusses the standard meter in Paris as embodying "how we measure length", the Panopticon describes "how we exercise power".

The technical production of subjects is a political affair, and one that most certainly does involve the distortion of power through domination, so the most pressing intellectual question concerns the legitimate response it may entail. Let us look at two theoretical approaches to elaborate a position on how subjects can cope with technically

\footnotetext{
${ }^{2}$ This is not tantamount to saying that capitalism invented disciplinary power, a thesis Foucault explicitly rejects (Foucault 1980, p. 105; Dreyfus and Rabinow 1983, p. 135).

${ }^{3}$ Canonically, Lukes defines power-over as three-dimensional: power as in regulation over people's behavior, power as in the control over what counts as legitimate political discourse, and power as in ideological mystification, making people do and accept things not in their interests.
} 
mediated power relations: a hermeneutic approach to the power of technological mediation (Verbeek) and a dialectic approach (Feenberg).

\subsection{Hermeneutic Power: Postphenomenology}

Verbeek (2011, pp. 66-89) incorporates a Foucauldian power perspective in his postphenomenological theory of technological mediation. Postphenomenology is Don Ihde's $(1990,1993,2009)$ name for a variant of Husserlian phenomenology, one purged of its transcendental and essentialist tendencies and injected with American pragmatism. From a historical point of view, postphenomenological mediation theory is an attempt to dislodge the philosophy of technology from the methodological bias that plagued so-called "classical" philosophies of technology, such as those of Heidegger, Ellul, Jaspers, and Mumford. Diverse as the analyses of these thinkers may have been, they were all informed by a transcendentalist conceptualization of technology, employing an approach that does not take as starting point concrete technologies, but probing into the conditions of possibility. For example, Heidegger (1977) identifies the essence of technology not with the general traits of specific artifacts but with the historical mode of the disclosure of being called "enframing," an attitude that conceives of nature as a stockpile of resources to be exploited by man. Inspired by the rise of science and technology studies (STS) in the 1980s and 1990s, Verbeek (2005) inverts this transcendental approach to technology by resolutely embracing what Achterhuis (2001) calls "the empirical turn." An empirical inquiry into the meanings technologies (in the plural) bear, so we are told, reveals a much less dark and much more pluriform image than classical philosophy of technology would have us believe (Brey 2010; Verbeek 2005, p. 66). This is not to say that the hermeneutic and existential questions raised by classical philosophy are not legitimate, as mediation theory recognizes, indeed, in steering a middle course between these and the empirical approach characteristic of STS.

From a systematic point of view, Verbeek presents postphenomenology first of all as a rejection of a naive instrumental conception of technology, that is, of the often disreputed view of technology as a means to an end (Heidegger 1977; Feenberg 1999). Implicit in this conception is a metaphysics of the human-technology relation as a modern ontology that classifies humans and technology as two distinct and essentially independent realms, epitomized in the modern Cartesian dualism of res cogitans and res extensa, the dichotomy between subject and object. The rejection of the adequacy of this picture for life-world situations ${ }^{4}$ is inspired among other things by the insight that technological artifacts play an active role in shaping human subjectivity, experience, and action.

Phenomenology is the study of intentional ${ }^{5}$ experiences, which in the end are constituted in "pure consciousness" (Husserl) or in the existential structures of "being-in-the-world" (Heidegger). Postphenomenology shifts the constitutive element

\footnotetext{
${ }^{4}$ Of course, rejecting this picture does not mean that it does not make sense tout court: it can be argued that the subject-object dichotomy characterizes the stance that the natural sciences take towards nature.

${ }^{5}$ Intentionality in phenomenology refers to the directedness of experience to an object, regardless of its (material) existence: "In perception something is perceived, in imagination, something imagined, in a statement something stated, in love something loved, in hate hated, in desire desired, etc." (Husserl 2001, p. 95)
} 
to the middle: neither subject nor object is primary or self-sufficient. ${ }^{6}$ For Verbeek (2005, p. 114), the mediating role of things takes place in this middle and relates to the very ontological status of subjectivity and objectivity:

Things are not neutral intermediaries between humans and world, but mediators: they actively mediate this relation. (...) Mediation does not simply take place between a subject and an object, but rather coshapes subjectivity and objectivity. (...) Humans and the world they experience are the products of technological mediation. (Verbeek 2005, pp. 114, 130; see also Verbeek 2012)

Verbeek's version of postphenomenology combines both Ihde's (1990, pp. 72-111) views on human-technology associations and Latour's (1994) on technical mediation. Whereas Ihde offers a way to analyze the mediation of experience, Latour provides for that of action. In addition, Ihde studies mediation, once constituted, as (from within) subjective experience, whereas Latour concerns himself with the various networks out of which mediations come into presence. Verbeek, however, focuses not so much on this "opening of the blackbox," because postphenomenology is interested "not so much in the networks of relations on the basis of which the mediating artifacts and the experiencing humans are present, but in the nature of the relations that human beingsthanks to these artifacts - can have to other humans and things" (2005, p. 166). Instead, Verbeek focuses on Latour's emphasis on hybridity, the manner in which agents of action ("actants") cannot be analyzed in terms of discrete human and non-human components.

Verbeek's approach, and postphenomenology in general, has been criticized on the grounds that the emphasis on how subjects and objects emerge through mediative relations obfuscates many other aspects that are important in technological cultures. Echoing Winner's (1993) complaint that the empirical turn goes hand-in-hand with a disregard for fundamental normative questions and the loss of a more systematic view on technology, for example, Kaplan (2009) argues that the exclusive focus on subjects and objects is insensitive to how technical artifacts, and indeed technical systems as a whole, do not merely mediate relations between an agent and the world, but also between society and the world (see also Feenberg 2009). Furthermore, there is no account in Verbeek's approach of the historical and social origins of particular mediations. Indeed, Winner (1986) and Noble (1984) have shown that technology can play a pivotal role in structuring and restructuring social relations, relations of power, and even class: "Postphenomenology would benefit from a detour through the rough ground of political economy. Otherwise, the materiality of things remains unexplained, if not naïve to illegitimate power and authority" (Kaplan 2009, p. 237).

Heeding this call, Verbeek (2011, pp. 66-89) refers to Foucault, both on power and to his later work on self-constitution. This, at least in part, allows Verbeek to counter objections of political naivety and an overemphasis on the descriptive. According to

\footnotetext{
${ }^{6}$ Mediation is not the only way in which to incorporate the technological constitution of subjectivity into phenomenology. Deploying "the logic of the trace," Derrida (1973) finds, at the heart of the purest spiritual mode of being, Husserl's phenomenological reduction, that which was supposed to have been erased: the material world, writing in particular. Stiegler (1998) transforms this logic into a philosophy of technology in which by means of "tertiary retentions" (i.e., technologies), the condition of the human subject becomes that of "originary technicity", i.e., in the sense of being originally constituted by technology.
} 
Verbeek (2011, pp. 28-33), the postphenomenological figure of technological mediation offers a way out of the deadlock of humanistic thinking about technology. The metaphysics of humanism, in Verbeek's view, reinstates a divide between what is genuinely (or even essentially) human (Kantian autonomy) and whatever is not (technology) (see also Latour 1993). In effect, any normative discussion about technology becomes a border check for technologies that overly impinge on human autonomy. However, the metaphysics of mediation denies any such rigid boundary from the outset: "We are as autonomous with regard to technology as we are with regard to language, oxygen, or gravity. It is absurd to think that we can rid ourselves of this dependency, because we would remove ourselves in the process" (Verbeek 2011, p. 155). But this depiction of humanism does not emerge out of any serious engagement with humanist authors, but, rather, deals with a straw man. The young humanist Marx of the 1844 Paris manuscripts, for example, introduces the notion as of human being as a "species-being" (1975, p. 329), a notion which would later be taken up and interpreted by critical theorist Herbert Marcuse (1973). Species-being corresponds to man's essence. But what is the character of this essence? For Marx, it signifies man's laboring activity, or more precisely, man as a productive, i.e., technologically productive being, productive of nature, of the world of objects, and productive of himself: man produces man. Man's consciousness of its universality constitutes its freedom (Marx 1975, p. 327f.). In other words, the essence of man Marx refers to in this case is not equivalent to some perennial autonomous sphere of human existence, which we should not dilute too much, rather man's essence is not opposed to history, but unfolds in its very process, or as Marcuse (1973, p.28) puts it: "man is taken up into the definition of his essence (...) essence (...) can be defined in history and only in history." And indeed, if we substitute "technology" for "nature" when Marx (1975, p. 328) writes that "[n]ature is man's inorganic body, that is to say nature is in so far as it is not the human body. Man lives from nature, i.e. nature is his body, and he must maintain a continuing dialogue with it if he is not to die," Verbeek's strawman is in fact his mirror image. But this mirror image does not want to give up on the belief that man can be alienated from his essence ${ }^{7}$ : the animal-like life of the factory worker under capitalism.

For Verbeek (2011), proper engagement involves neither rejecting technology nor embracing it wholeheartedly (see also Ruivenkamp 2005), but asking which "technologically mediated subjects" we want to be, as a preference, a question of value, about the good life. This is an ethics not geared to humans or to technology alone, but to "human-technology associations." And at this point, power makes its entrance. Foucault notoriously suggested that our reflexive experience as autonomous subjects, as modern liberal ideology has it, is a construction of disciplinary power, aptly captured in the inverted Platonic image in which "the soul is the prison of the body", monitoring and (self-) disciplining its "docile body" (Foucault 1977, pp. 30, 141). Instead of taking this as a gloomy, nihilistic assertion, however, Verbeek (2011, p. 66) reads it as an underscoring of his own theory of technological mediation: subjects are constrained and produced by relations of power, among which some are technically mediated, but we are not thus determined, and we have the ability to rearticulate our technologically mediated subjectivity.

\footnotetext{
${ }^{7}$ Next to the three other forms of man's alienation Marx (1975) identifies: from the product, the work process, and his fellow-man. Also note that private property, and not technology as such, is the cause of this alienation.
} 
In this paper, however, we are interested in the relations between capitalism, power, and technology. While not explicitly addressing capitalism, Verbeek (2011, p. 71f.) does indicate a position in respect of Marxism:

When power is what makes us the subjects we are, after all, a merely subversive and rebellious attitude towards power does not offer a real alternative. I read Foucault's concept of power in a hermeneutic way rather than incorporating it in a Marxist dialectic of oppression and resistance. In a hermeneutic reading, human beings derive their subjectivity from interplay with the structures of power in society-just as entities in general derive their meaning in interaction with the context in which they exist. Opposing these power structures would be nonsensical, since every attempt to escape them can be made only in terms of these powers themselves. ${ }^{8}$

On this reading of the dialectical scheme, if technology is seen as oppressing mankind in one way or another, then resistance becomes its antithesis and liberation the sublation. Again, what sense can we ascribe to this paragraph? Verbeek seems to suggest that dialectics are completely blind to hermeneutics, but this is blatantly wrong. For what is historical materialism? The methodological premise that we should understand human existence and society against a historical, hermeneutic background of productive forces and their (corresponding or conflicting) relations of production. To play some word-substitution again: replace "interplay" with "dialectics" in the quoted fragment, and Verbeek looks upon his mirror image again. ${ }^{9}$ As we have discussed, Marcuse (2002), for example, drawing on the Hegelianism of the young Marx, argues that in capitalist technological consumer society, man's existence, has been alienated from his essence. That is to say, the human essence of freedom and self-fulfillment are estranged in the relations of production under capitalism, in part due to the specific technological commodities it generates. Only through the "Great Refusal" (Marcuse 2002, p. Xxxv) of this condition can existence and essence be rejoined. A sublation consists in such a transformation of the technical system that treats nature with the same respect and care as would befit humans, instead of that of the domination, control, and exploitation characteristic of capitalism. It is noteworthy that Marcuse's dialectical view does not encompass a wholesale rejection of technology; the point of dialectical Aufhebung is that we do not throw out the child with the bathwater, but raise it to the phase of maturity. Remember that for Marx himself communism is the Aufhebung of capitalism: it is that which capitalism, unleashing the forces of human production to their greatest historical height, becomes when it sheds exploitation.

Verbeek's refusal to adopt the Marxist dialectical approach seems to entail more; it is a specific political stance towards capitalism and the technologies developed under its relations of production. We take it to entail three points. First, it consists of a denial, similar to his rejection of the late Heidegger's work, that every technology developed under capitalism has as its only social meaning that of exploitation, domination, and

\footnotetext{
${ }_{8}^{8}$ The assertion that power produces resistance is certainly a train of thought to be found in Foucault's work. Verbeek seems to suggest that all forms of resistance are produced by power. A more subtle problem with this anti-dialectical position is that it neglects the full import of the "equiprimordiality" of power/resistance, by granting complete primacy to power.

${ }^{9}$ We thank this point to one of the anonymous reviewers of this article.
} 
control: "Modern communication technologies, for instance, make it possible for human beings to interact with others outside of their immediate environments without necessarily approaching these people from a 'will to power.' And medical technologies (...) depend on (...) care and respect" $(2005$, p. 66). Of course, a dialectician like Marcuse can easily fend off this objection by arguing that what Verbeek, and indeed most of what is claimed by the empirically oriented sociology of technology, such as STS with its emphasis on micro-level studies, is, in fact, both true and false: true at the level of local practice, but false from the perspective of "totality", and thus also fundamentally untrue. The premise to Marcuse's dialectical approach being that any investigation that endeavors to interpret society by solely analyzing one of its parts can only remain at the level of semblances. Only by analyzing society in its totality, and its unifying principles, can we move from semblance to truth. Modern communication technologies indeed enlarge the scope of its users' life-world, but they are also commodities in a capitalist system suturing subjects to the capitalist mode of production and consumption.

On a more generous reading, and secondly, the lesson to be drawn from Foucault's elaborations on power is that power-relations are inevitable: "[Freedom] is not to be found in the absence of influences that constrain the subject but, rather, in dealing with these influences. (...) One becomes a subject not by securing a place outside the reach of power but by shaping one's subjectivity in a critical relation to it" (Verbeek 2011, p. 73). Verbeek (2013) claims that power should be understood as a web of relations that give meaning to the life-world of subjects, more akin to what Ihde calls macroperception, or what Wittgenstein calls forms of life, than to Nietzsche's will-topower. Capitalist power relations, while not explicitly thematized by Verbeek, are a subset of the many relations of power that constitute the current hermeneutic background that gives meaning to the technological life-world of subjects, and thus it produces the way we think, act, and perceive. In this view, we have to deal "responsibly" with capitalist power relations for better or worse, "except in cases of complete domination, where technological mediation makes room for force and compulsion" (Verbeek 2011, p. 87). What is completely lacking in this approach to Foucault's work is the fact that the very form the production of subjectivity takes is political in its own right, i.e., not merely a more or less neutral hermeneutic background; capitalism is a political project which deploys the production of subjectivities attenuated to its requirements of capital accumulation.

Third, we need a response; if we accept the claim that a merely rebellious and subversive attitude towards technologically mediated power relations is a dead end street, then what remains of the category resistance? Dorrestijn (2012) and Verbeek (2011, p. 82-89) have developed a framework for understanding how technologically mediated subjects can thematize and reconstitute power relations embedded in artifacts. Again, they refer to Foucault, but not to his middle work on power, but to his later work on self-constitution. In their reading, self-constitution is explicitly ethical, as opposed to political. In line with a hermeneutic reading of power, resistance is conceived as the capacity of subjects to explicitly take a stance towards mediating technologies that shape their environments. It is their capacity to find new forms of use, or to explicitly choose certain uses of artifacts over others, or to even be involved in the very design process of technologies, that is the locus of resistance: 'In a technological context, self practices consist in using technology deliberately by anticipating and modifying its 
mediating role in our existence, realizing that each way of using it also helps to shape our subjectivity. Such self practices could be described as "techniques of using technology".' (Verbeek 2011, p. 84) Even if one might ponder why one should call such practices resistance - doesn't one always resist something? - the sense we can deduce from it is a conservative political agenda: we should not negate our current capitalist society and its concurrent technologies, but seek for manners to develop a good life amidst these relations of power.

\subsection{Dialectic Power: Critical Theory of Technology}

The social implications and historical origins of technology development insufficiently highlighted in postphenomenology are at the heart of Feenberg's critical theory of technology (1991, 2002), or critical constructivism (1999, 2010). Upon opening the technological black box, Feenberg does not find it empty, but filled with that category frowned upon by actor-network theorists yet ever so central to classical Marxist analysis: ideology (Feenberg 1999, p. 8). Like those of Ihde and Verbeek, Feenberg's approach is as suspicious of the all-encompassing grand theories of classical theory as of naïve instrumentalism, even if he does explicitly align himself in a tradition often criticized for possessing "substantive" 10 tendencies, to wit, the Frankfurt School of Adorno, Horkheimer, Benjamin, and (for Feenberg) especially Marcuse. This critique of substantivism is reiterated by Brey (2010), who also includes the critical theorists Marcuse, Adorno, and Horkheimer under this label, as entailing three components: first, the image projected by these thinkers of modern technology was too dark, gloomy, and pessimistic (see also Kiran and Verbeek 2010). This negative image belongs to the post-war era and 1960s counterculture but "the mood had shifted in the 1980s and 1990s, and a different image of technology was emerging in the collective consciousness that saw technology as more ambivalent: as a force that was used for both good and ill" (Brey 2010, p. 3). The second point is the attribution of technological determinism to critical theory in which technology is conceived as an autonomous and unstoppable force "rooted in scientific-rational principles and [which] did not involve true human choices" (Ibid.), a view which came under fire by STS scholars, who emphasized the contingency and social construction of technology (Bijker et al. 1987). The third point of criticism against critical theory is a methodological one, viz., that critical theory studied technology with a capital " $\mathrm{T}$ " instead of technologies in their multifaceted empirical meanings. However, from the start it should be noted that the various authors of the Frankfurt School all entertained different ideas on how to come to terms with the challenge posited by Lukács and his category of totality, i.e., the fundamental primacy of the whole over the parts, the relation between theory and praxis, and the reifications in capitalist society (Jay 1984, see also Feenberg 2014). Furthermore, to attribute such predicates as "gloomy", "dark", or "pessimistic" to an approach lacks argumentative force as such, nor does a change in mood in the spirit of times render a previous approach obsolete. Associating technological determinism of an unstoppable, autonomous kind with the Frankfurt School is not only rhetorical but simply false. If we take, again, Marcuse (1960) as an example, he proposes a negative,

\footnotetext{
$\overline{{ }^{10} \text { Substantivism is Feenberg's }}(1999$, p. 9) name for philosophies of technology, which conceptualize technology as a force with its own logic of domination.
} 
Hegelian thinking in which the possibility of a "determinate negation" is never excluded, that is to say, the negation of the negation may lead to a positive resolution in which an alternative arises which goes beyond the status quo. In less metaphysical and more practical terms, this means that the capitalist technical system may be transformed in a radical fashion, such that it may serve instead of inhibit human freedom. It is true, however, that we find in Marcuse (2002, p. 157f.) the mutual, and essential, dependence of modern science and technology on the one hand, and political domination on the other: "The science of nature develops under the technological apriori which projects nature as potential instrumentality, stuff of control and organization. (...) [W] hen technics becomes the universal form of material production, it circumscribes an entire culture; it projects a historical totality —a 'world'." But this a historical totality, and not a deterministic one. The third objection to critical theory is not one without its history (Adorno et al. 1976). It suffices here to note that what looks like an objective, empirical description is nothing more than bourgeois ideology seen from the other side.

Feenberg's redefinition of the project of critical theory departs from that of his predecessors in critical theory in two important regards. First, very broadly, classical critical theory was informed by the insight that "instrumental rationality" undergirding modern scientific technology development was intrinsically intertwined with capitalist domination. ${ }^{11}$ Feenberg's (1999, pp. 202-205; 2002, pp. 175-177) instrumentalization theory counters this substantive legacy in critical theory by the proposal of a dual level analysis of the essence of technology: the functional aspect of the essence of technology is captured in the so-called "primary instrumentalization," which decontextualizes nature in the attitude that Heidegger calls "enframing" and re-contextualizes it in accordance with some kinds of affordance discovered. This process of de- and recontextualization involves power insofar as that nature and subjects are "instrumentalized" in terms of functionality. For any technical device or system to actually function, however, it must be implemented in an environment, which is natural, technical, and social.

At this natural, technical, and social level, the level of meaning, the secondary instrumentalization comes into play, that of social power. "The mediation is the message" (2013a) insofar as that Feenberg, paradoxically, denies an opposition between neutrality and bias, between means and ends. In his view, social valuesideology, if you like (2010, p. 68) - are pre-inscribed in the very means, in technologies. Especially in such politically relevant, technically mediated social domains as agriculture, medicine, public transport, and infrastructure, Feenberg (1999, p. 88; 2002, pp. 76f.; 2010, p. 68f.) finds a technical code at work, presiding over the development of these mediations.

As suggested by the term, technical codes are literally as well as metaphorically written (at the design level) and read (in society), and have a surreptitious, nontransparent character. This character consists in the fact that once written into a technical artifact it eo ipso erases its ideological and cultural underpinnings. For example, before barrier-free design became common, the standard code written into sidewalk design was that disability was a private problem, and thus the disabled were discriminated against. Only by rewriting this code, by making it a public issue (e.g.,

${ }^{11}$ See, for example Adorno and Horkheimer's (2007) classical analysis of the Culture Industry. 
through disability rights legislation and its practical implementation in design), was this bias stated as a problem, and thus resolved. That is to say, in a lot of cases, the technical code obscures the fact that a solution to a technical problem is underdetermined by technical feasibility and coherency, and "co-determined" by values. The insight that specific technologies emerge as the contingent outcome of struggles over value links Feenberg's work to the empirically oriented philosophy of technology and STS rather than classical critical theory, which tried to interpret the whole of society from the perspective of totality, for example, by the general form of the commodity, or the generalization of instrumental rationality to all domains. Put differently: formal bias is what neutrality becomes when it is divorced from the design room and wedded to societal context (Feenberg 2002, pp. 80-82). The most tenaciously biased of technical codes is that of capitalism, pre-inscribing class bias in terms of efficiency, access, and the deskilling of the labor force into the means, of which the assembly line remains paradigmatic: "[A] strategy of technologically enforced labor discipline forms the glue that holds together the elements. This asymmetrical effect on power is characteristic of a strategically encoded technology" (2002, p. 78). Power, in Feenberg's view, possesses both a "subjecting" component, in terms of the dominated subjects it produces, and a "class power" one, in terms of an asymmetry of the distribution of power over the forces of production; capitalists (1991), or "elite classes" (2010), consolidate and reproduce their hegemony by wielding "operational autonomy" over the design of the technical system. Feenberg (2002) explicitly acknowledges Foucault's work, but in the end remains closer to critical theory by localizing power in the rule over the technical system through class bias and technocracy.

However, and contrary to many descriptively oriented empirically informed technology studies, Feenberg is not prepared to let go of the anti-capitalist socio-critical baton bequeathed to him by the Frankfurt School, and configures his notion of resistance along ideologico-critical lines: a normative evaluation of the technical system is not based on "arbitrary opinions," but on the dialectical notion of Hegelian-Marxian "negativity." It is the very suppressed, ignored, and threatened needs of individuals that society fails to address which harbor in themselves the potentiality of a reconfiguration of the technical system. Resistance is the practice when "those threatened by technology (...) control technology" (Feenberg 1995, p. 207), when users voice public protest, of course, but also when they reinvent for novel uses or engage in participatory design. It is the antithesis of the rejection of technology that comprises the impetus for a sublation, in which previously hidden potentialities are incorporated into technical mediations. Or put in Feenberg's own terms: secondary instrumentalizations are the locus for a democratic, "subversive" rationalization of historically sedimented technical designs.

In a sense, we can see here that Feenberg's dialectical approach, in practice, is not so far removed from Verbeek's call for thinking the good life as a question of the choice between several possible trajectories of technically mediated subjectivities opened up by technological innovation, be it that Feenberg is more interested in the political process that results in technological mediation, whereas Verbeek focuses on the corresponding subjectivity. As Van Den Eede (2011) argues, postphenomenology and critical theory of technology render some aspects of technological mediation opaque and others transparent. If postphenomenology is good at analyzing the transformative experiential dimension of technological mediation, then critical theory highlights biases that may otherwise go unnoticed. 


\subsection{A Struggle Between Spheres or the Question of Resistance?}

One way of conceptualizing the philosophical clash between the hermeneutic postphenomenological approach and the dialectics of critical theory is to evoke the metaphor of a struggle between spheres. Dorrestijn (2012), for one, argues that the notion of co-constitutive technical mediation developed by Ihde, Latour, and Verbeek is fundamentally at odds with the critical theories of Feenberg, Kellner, and Kirkpatrick. The latter, he argues, have not sufficiently shed off the legacy of the Frankfurt School, in which the sphere of technology, power, and capitalism is seen as disrupting some preconceived sphere of authentic human existence. But we have already seen in our discussion of Verbeek that the attribution of such a preconceived sphere to classical critical theory is based on a straw man. Verbeek (2013) provocatively suggests that resistance, as configured in Feenberg's critical theory, is futile insofar as it adheres to a reificatory conceptualization of power, which Foucault was so intent on dismantling ${ }^{12}$; Feenberg's dialectical conception of power tacitly reinstates the modern divide between humans and technology, in which technology is seen as threatening society in one way or the other, or put differently, in which technology and society are at struggle.

In reply, Feenberg (2013b) concedes that his previous dialectical terminology of the dominating and the oppressed was misleading, and that, in fact, his project is very much in line with Verbeek's postphenomenology in looking for ways in which technological mediation can shape the good life. In fact, his very instrumentalization theory is based on the acknowledgement of the technological constitution of subjectivity, the whole point of his notion of a code being that subjects are technically constituted, but that this constitution may be beneficial or detrimental to one social group or the other. ${ }^{13}$ Struggle is no doubt at work in Feenberg's work, but this struggle is not between technology and society, but between social groups with differing interest over the technical system.

The congeniality between the approaches of Feenberg and Verbeek is adumbrated in their conceptualization of resistance as some form of democratization of technological design - and this is the line of thought we want to call into question. In itself, any notion of "democratization" remains empty: the precise way in which it is filled out is crucial. Feenberg, in Transforming Technology, identifies democratization with the civilizational project of overturning capitalism and instituting socialism. Socialism, collective ownership of the means of production, is tantamount to democracy insofar as there is no specific social group or class that is favored by the possession of operational autonomy over the technical system. In his more recent work, however,

\footnotetext{
$\overline{12}$ While Foucault's Nietzschean genealogical analysis of how the Enlightenment project, aimed at the liberation of mankind from unwarranted traditional dogma, was in fact complicit to its further oppression, bears a striking resemblance to Adorno and Horkheimer's dialectical argument of how liberation entailed its contrary position, and Foucault's acknowledged debt to the latter- "I acknowledge the merits of the Frankfurt School philosophers, I do so with the bad conscience of someone who should have read them long before"(Foucault 2002, p. 274), we do also find remarks, which support Verbeek's position: "Simplifying things, one could say, for the moment, that the conception of the subject adopted by the Frankfurt School was rather traditional, philosophical in nature - it was permeated with Marxist humanism" (ibid.).

${ }^{13}$ Lotz (2011) points out, however, that Feenberg does not elaborate on the category of the "social" enough, and veers close to a form of "social idealism," the position in which technology development is merely the outcome of social struggle, neglecting for example that technology development itself transforms the embodiment in which social struggle takes place.
} 
Feenberg's position has gravitated towards pragmatism in looking for ways to mitigate the effects of capitalist hegemony within the system itself (Hickman 2006).

For example, Feenberg's (1999, pp. 140-147) notions of "participant interests" and "deep democratization" still have a remotely dialectical ring to them in the sense in which marginalized interests challenge hegemonic ones, but they are far removed from the Marxist tradition in trying to reduce "the operational autonomy of experts and managers," as well as combine "the democratic rationalization of technical codes with electoral controls on technical institutions" (ibid., p. 146). What is postulated in more radical versions of Marxism is the thesis that problems of power and authority cannot be resolved within the framework of the bourgeois state, its institutions, and its republic of property, or rather, that this framework with such distinctions as public/private, producer/consumer is part and parcel of the very problem (Hardt 2010).

Verbeek (2011, p. 89-121), wary of allegations of apologetics to technocracy, also calls for the democratization of technical design through user involvement. The impact of technical mediation on the good life leads Verbeek to the question how engineers, in the design process of mediating artifacts, can explicitly engage with this impact in a normative way. ${ }^{14}$ Put another way, if the "technical design of life" is not to lapse into technocratic rule, the users of these mediating artifacts need to be consulted. Contrary to Feenberg's reference to socialism, Verbeek (2005) builds this technical design of the good life around the (ideal of) liberal democracy.

It should not go unsaid that Feenberg's sympathy for phenomenology and pragmatism has a history of animosity, and that his concessions are far from unproblematic. Adorno (1973) launched a vehement attack against Heidegger's Kierkegaardian "fideism", defending critical reason against a cultus of "authenticity". But aside from polemics, Adorno (2013) engaged into a more thoroughgoing "deconstruction" of the very foundations of phenomenology, viz., Husserl's notions of evidence, phenomenological reduction, and eidetic reduction. In particular, Adorno refuses the phenomenologist's assumption that experience can be the starting point of philosophical analysis; in Adorno's view subject and object mediate one another dialectically, always being transformed by the other. Also, the ideological underpinnings of pragmatism could not withstand the critique Horkheimer (1947) leveled against it, who derided its explanation of truth in terms of success as veiling a longing for capitalist acquisition of wealth.

To return to our discussion, Verbeek's position differs from Feenberg's not fundamentally but only in terms of emphasis: the essence of resistance boils down to "more democratic and participatory procedures" (Feenberg 2010, p. 213). In capitalist society, one may surmise that such participatory engagement remains severely limited for the simple reason that there is no incentive for industry to engage in any significant democratization for any reason beyond that of the market (cynically, as contributing to its own dynamic) or public institutional force (under duress, as required by or through the authority of the state) (Brey 2010). For Verbeek (2013), albeit not neglecting the democratization of technology, Feenberg indulges in what Foucault $(1997 \mathrm{c})$ called the "blackmail of Enlightenment", the false dilemma in which if one

\footnotetext{
${ }^{14}$ This line of thought is also present in the work of Hardt and Negri's Marxist appropriation of Foucault, namely, that "immaterial labor" is directly "bio-political", i.e., productive of the forms of social life. This politico-economic dimension of the production of subjectivity is completely lacking in Verbeek's analysis.
} 
does not fully embrace an emancipatory agenda, one is against it: either technology is democratized through more electoral control and the development of democratic institutions, or ruthless technocracy shall be our fate. As we have seen, for Verbeek self-practices in which subjects shape their technical environments present an alternative form of democratization. But does not this take us back to where we came in, to a new form of blackmail? One either accepts the current liberal private-public framework and the capitalist system, or "resistance is futile"?

\section{Technological Mediation and Autonomist Marxism}

"Even though common use of the term might suggest the opposite - that resistance is a response or reaction - resistance is primary with respect to power" (Hardt and Negri 2004: 64). This common usage of the term "resistance" can be found in the power perspectives on technological mediation elaborated in postphenomenology and critical theory. Conceptualizing resistance as such is a specific political choice, or, more precisely, a choice on the form of political struggle: we either accept capitalism as the current hermeneutic background against which all forms of technological mediation must inevitably take place, or we negate capitalism by trying to reduce its destructive force. In both approaches, however, the position of subjects is reactive in the sense that primacy, in the end, is granted to capital, to which labor can respond in one way or the other.

\subsection{Biopower and the Social Factory}

Autonomist Marxism is that school of Marxism centered on the class struggle (Wright 2002), as opposed to more conventional political economist readings of Marx focused on capital accumulation, or philosophical ones such as those of the Frankfurt School (Cleaver 2000). Class, per definition, is the relation of a social group to the means of production, and class antagonism comes to the fore when a class constitutes itself as engaging in struggle, as resisting. In The Communist Manifesto, Marx and Engels (2002) identify the antagonism between the proletariat and the bourgeoisie as the catalyst for revolutionary change: the proletariat is identified as the revolutionary subject for the very reason that it is able to constitute itself as a class of resistance against capitalist domination, as opposed to, say, the lumpenproletariat, that class of "proletarians" never likely to gain class consciousness. This primacy in politico-economic analysis of the class struggle from the perspective of labor and the constitution of the working class as agent of resistance form the cornerstones of 1960s and 1970s Italian operaismo or workerism, out of which present day (post) Autonomia (and post-Operaismo as well) branched. ${ }^{15}$ The central antagonism in capitalist society is that between those who produce and those who appropriate. But while capital, for its survival and reproduction, needs the productive forces of labor as the source of surplus value, the inverse does not hold: in theory, labor is autonomous (Dyer-Witheford 2004, p. 7).

\footnotetext{
${ }^{15}$ Operaismo refers to the Italian school of Marxism focused on factory workers, revolving around such figureheads as Tronti and Panzieri. Autonomia signifies a more broad social movement, of which Negri is the most well-known proponent (Dyer-Witheford 2004, p. 25).
} 
In its study of the elements that constitute power relations in capitalist class society, present day autonomists rely just as heavily on the neo-Nietzscheanism of Foucault and Deleuze as they do on the more traditional, Marxist dyad of capital and labor-and which forms the connection to the discourse on technologically mediated subjectivity. In effect, the dialectical Hegelian-Marxian notions such as "totality", "alienation", and "sublation" are replaced by Foucauldian and Deleuzian notions such as "dispositif", "control" and "biopolitics" (Berardi 2009, p. 116). In particular, efforts have been made to transpose the Foucauldian notion of biopower onto a Marxian framework (Berardi 2005; Hardt and Negri 2000, 2009; Lazzarato 2002, 2004; Negri 2008a, b).

Foucault (1978, pp. 135-159; 2003, pp. 242-262) identifies biopower as the eighteenth century emergence of a set of techniques aimed at the (biological) management of the productive forces of populations and the discovery of man as a speciesbeing, ${ }^{16}$ which came to full fruition in the welfare-state model. It includes such regulatory mechanism as health-insurance systems, rules of public hygiene, statistical predictions of mortality rate, child-care, or in short the very fostering of life, instead of the denial of life characteristic of sovereign power. Although Foucault differentiates it, as do the autonomist, from disciplinary power, which is aimed at the drilling and exercising of individual bodies, he does speak of infiltration: "This technology of power does not [...] exclude disciplinary technology, but it does dovetail into it, integrate it, modify it to some extent, and above all, use it by sort of infiltrating it, embedding itself in existing disciplinary techniques" (2003, p. 242). As Nealon (2008, pp. 83-85) has pointed out, the link between autonomist Marxism and Foucauldian biopower can be found in the autonomists' reliance on a short segment from Marx' Grundrisse, "The Fragment on Machines" (Notebooks 6 and 7), in which Marx speculates that with the advent of machinery, a new form of labor altogether arises, viz., the moment when all facets of social life become a force of production:

The production process has ceased to be a labour process in the sense of a process dominated by labour as its governing activity. Labour appears, rather, merely as a conscious organ, scattered among the individual living workers at numerous points of the mechanical system; subsumed under the total process of the machinery, as itself only a link in the system, whose unity exists not in the living workers, but rather in the (active) machinery, which confronts his individual, insignificant doings as a mighty organism. (Marx 1993, p. 693)

For Negri (2008b, p. 230) Foucault's analysis of the advent of biopower is "the other side" (i.e., in terms of the exercise of power instead of Marxian politico-economics) of Marx' description of the transition from formal subsumption of labor under capital to real subsumption of labor under capital. Formal subsumption is the dialectical, proletarianizing process by which previously existing labor processes (e.g., agriculture) are brought under capitalist wage-labor relations. This process relies on an "other", nonproletarianized field of labor which capital subsumes under its relations of production (as it were centrifugally). But at a certain point this process must come to a halt; real subsumption is the process by which capital starts fashioning the labor process, and indeed, society as a whole (as it were centripetally) (Dyer-Witheford 2004, p. 10; see

\footnotetext{
$\overline{{ }^{16} \text { Sexuality being his prime example. }}$
} 
also Griffioen and Van Tuinen 2009). For the autonomist more generally, biopower refers to the power over life, when life itself is put to work under capitalist exploitation, when individual and social life itself are subsumed under capitalist sway (Casarino and Negri 2008; Lazzarato 2004; Morini and Fumagalli 2010). No longer limited to the confines of the factory, the capitalist mode of production permeates the entire social field, including public and private life, or in short, the (technical) production of subjectivity itself. Another way of saying this is that the real subsumption of society under capital (Negri) is the "total triumph of Foucauldian biopower" (Nealon 2008, p. 84).$^{17}$ In terms of technology, following Deleuze's (1995) brief sketch, Hardt and Negri argue that with the rise of among others digital networks, we have witnessed a qualitative shift in the hegemonic form biopower takes: "The society of control might thus be characterized by an intensification and generalization of the normalizing apparatuses of disciplinarity that internally animate our common and daily practices, but in contrast to discipline, this control extends well outside the structured sites of social institutions through flexible and fluctuating networks" (2000, p. 22). ${ }^{18}$ Berardi (2009) points to the example of precarious flex-workers whose mobile devices make them permanently available at-a-distance, everywhere, at any time of the day. In consonance with the diffusion of the factory throughout social life, the class struggle is re-conceptualized accordingly. No longer taking place solely, or even most importantly, between the blue-collar worker and the entrepreneurial capitalist, but spread throughout the socius, the exploited class includes white collars, peasants, houseworkers, hackers, or what Hardt and Negri (2004) and Virno (2004) call the "multitude": a heterogeneous set of singularities potentially united in a struggle, as much as the industrial proletariat was in the time of Marx and Engels, against the exploitation of biopower.

\subsection{The Power of Antagonism}

Biopower understood as the proliferation of the capitalist mode of production throughout social life is not the only Foucauldian insight the autonomist incorporates:

[T]here is always a minor current that insist on life as resistance, an other power of life that strives toward an alternative existence. The perspective of resistance

\footnotetext{
${ }^{17}$ And of course, this is only a short step away from the second pivotal concept the autonomists derive from the Grundrisse, that of the general intellect or of immaterial labor. For, if social life itself becomes a force of production in its own right, this implies the capitalist exploitation of knowledge and skills so central to contemporary cognitive capitalism: "The accumulation of knowledge and skill, of the general productive forces of the social brain, is thus absorbed into capital, as opposed to labour, and hence appears as an attribute of capital, and more specifically fixed capital, in so far as it enters into the production process as a means of production proper" (Marx 1993, p. 694).

18 The criticism that their Deleuzian appropriation of Foucault is exegetically not true to Foucault's work has been leveled at Hardt and Negri by Rabinow and Rose: "This conception of biopower is quite antithetical to that proposed by Foucault: the concept is emptied of its critical force-it can describe everything but analyse nothing. (...) [Biopower] was not trans-historical or metaphoric, but precisely grounded in historical, or genealogical analysis" (2006, p. 199). For Rose and Rabinow, biopower refers to a specific power technique aimed at the health of populations and does not necessarily serve the power-bloc of capitalism. In defense of Hardt and Negri, it can be noted that Foucault does see biopower as "designed to maximize and extract forces" (2003, p. 246), or the even stronger claim that their "metaphoric" reading of Foucault is true to Foucault by not "reading" him but by "using" his ideas as a "toolbox".
} 
makes clear the difference between these powers: the biopower against which we struggle is not comparable in its nature or form to the power of life by which we defend and seek our freedom. To mark this difference between the two "powers over life," we adopt a terminological distinction, suggested by Foucault's writings but not used consistently by him, between biopower and biopolitics, whereby the former could be defined (rather crudely) as the power over life and the latter as the power of life to resist and determine an alternative production of subjectivity. (Hardt and Negri 2009, p. 57) ${ }^{19}$

Capitalist development relies on a subject, the working class, that is internally antagonistic to capital's goals of the maximization of profit: Not only does the working class strive for a reduction of labor time or an increase in wage, it can also resist by means of "the refusal of work" (sabotage, coming in late, etc.). Moreover, "refusal of work" can also have a positive meaning, namely to refuse to work for capital by developing modes of production outside capital relations and instituting the corresponding subjectivities. These two meanings of resistance coincide nicely with the ones Foucault envisaged: power works on resistance, and is indeed dependent on it. For example, the power relation that is discipline needs the prisoner, who will not be turned into a docile body, or "normalization" only functions by categorizing "abnormal" individuals:

"You see, if there was no resistance, there would be no power relations. Because it would be simply a matter of obedience. (...) So resistance comes first, and resistance remains superior to the forces of the process; power relations are obliged to change with the resistance. So I think that resistance is the main word, the key word, in this dynamic." (Foucault 1997d, p. 167, emphasis in original)

Deleuze (2006, p. 74) captures this insight, running ambiguously through the work of Foucault, in the slogan that "The final word on power is that resistance comes first." But for Foucault resistance can also go beyond saying no:

\footnotetext{
${ }^{19}$ To be sure, Hardt and Negri's blend of Marx and Foucault has problems of its own and has indeed met with vast criticism, from both traditional and autonomist Marxists alike. According to Callinicos (2001) Hardt and Negri replace historical materialism with a theory of power and subjectivity, and by doing so lose sight of all valuable in politico-economic analysis (the concept of value, wages, the division of labor etc.) in descriptive terms. But this critique also extends to their adherence to a "postmodernist" conceptions of hybridity and multiculturalism which he claims do not provide any strategic means for battling the inequalities caused by globalization (see also Sprague 2011). In a similar vein Thompson (2005) rejects any reconciliation between Foucauldian and Marxist approaches and even sees Hardt and Negri's "smooth" capitalism as apologetic to the status quo. Moreover, their conception of a dispersed, but unified multitude fails to understand the dynamics of class composition. We tend to agree with this critique insofar as that Hardt and Negri never reflect thoroughly on their mixture of Marx and Foucault, although we do not find Foucault's power concept unintelligible as Thompson does. At the time of writing Discipline and Punish and the first volume to The History of Sexuality Foucault's main adversaries were "orthodox" Marxists (as opposed to Marx himself) who believed that power in capitalist society could be battled by abolishing class power only. Foucault's intention was, of course, to show how such mere dispossession could leave power relations in their place. But this does not necessarily imply that class power and Foucauldian power cannot meet: the very example of commonsbased production we refer to on page 19 exhibits that "subjectivation" and (struggle against) class power can accompany each other.
} 
Resistance was conceptualized only in terms of negation. Within your understanding, however, resistance is not merely a negation but a creative process; to create and recreate, to change the situation, actually to be an active member in that process (Foucault 1997d, p. 167). ${ }^{20}$

When grafted onto a politico-economic context, resistance becomes the practice when labor challenges capitalist relations of production not through an ideological critique of the superstructure, as Feenberg has it, ${ }^{21}$ but in the productive circuit itself. And contrary to Verbeek's suggestion that such resistance is inherently technophobic, this resistance can be technically mediated itself: We can think, for example, of Söderberg (2007), who has studied the activities of the Free Software movement in the 1980s and 1990s as a form of class struggle that tried to challenge the relations of production of proprietary software by subverting this very relation in the productive process. Stallman (2002) describes his practices of the initiation of the free software movement and its "copyleft" GNU license as a practice of technical self-constitution that is not merely rebellious but productive of new relations of production in its own right. Stallman opposes the de-autonomizing ways in which proprietary software functions in both development and consumer environments, and proposes an alternative strategy of producing and consuming software in which the opposition between user and producer is reconfigured, and in which subjects are enabled to rethink and modify the software that animates their daily interactions (see also Gorz 2010, pp. 114 129; Moulier Boutang 2011, pp. 83-91). This resistance is not reactive, but active and creative, because it opens new routes toward subjectivation, inventing new paths towards a regained autonomy. As Lazzarato (2002) points out, resistance is a set of strategic relations, just as dominating power is, but a set that thwarts any system of domination by inventing new subjectivities through a reversal of the asymmetrical dispositifs which that very system institutes (see also Negri 2008a, b). The point of resistance here is that it does not negotiate the values of the technical system, as in Feenberg's theory, but transforms the very relations, and subjectivities, on which production is based. In the latest installment of their Empire trilogy, Commonwealth, Hardt and Negri identify the common(s) as an alternative production system to either state-governed (the public) or market-governed (private) systems. Examples of such commons-based production models with regard to cyber-commons are described by Benkler (2006) under the heading commons-based peer production. Ruivenkamp (2005) points to the example of alternative ways of deploying biotechnologies outside of corporate proprietary, industrial relations, but in support of local agricultural development. We could call such practices "technologies of the self", with the added remark

\footnotetext{
${ }^{20}$ Of course, Foucault himself did not see the class struggle as the most perennial, or even most important power-relation, if only for the fact that it locates power in the capital-labor relation as opposed to his own "capillary", bottom-up, investigation into the micro-physics of power.

${ }^{21}$ Feenberg's dialectical roots are evident when he writes apropos of Deleuze that " $[\mathrm{t}]$ he reference to an amorphous subject of resistance constituted prior to the cultural encoding of individuality offers only a prerational basis for opposition: chaos or madness as a metaphor for political opposition. (...) It seems obvious that resistance must operate not merely on the level of microtechniques, but at the level of metapowers if it is to counter this constructive movement of capitalist hegemony". (...) [Marcuse] admits that most forms of resistance, vital or not, can be absorbed by the system, and that, far from threatening it, they contribute to its dynamism (2002, p. 71).
} 
that they do not remain limited to the existential level, but in fact represent a "government of the self and others" at the collective level.

However, akin but in the end dissimilar to Marcuse's notion of repressive desublimation, in which the system is able to deploy counter-resistances in order to uphold and strengthen its own hegemony, autonomists are very aware of the fact that resistance does not necessarily overthrow the system in a simple act of affirmative antagonism. As the stated example of free software perfectly illustrates, we have witnessed in the last decades the rise of corporate open source software development (OSI, Apache, Android), conceived as a business model in the service of capital- to the ironic extent, even, of the CEO of the world's largest social network describing himself as a "hacker" (Newfield 2013). Interestingly, though, this does support the notion of capital as a reactive force (Deleuze 1986): aimed at controlling and incorporating practices of freedom, capital continuously restructures the relations of production in response to the ongoing struggle of labor towards freedom. Negri (1991) couches this relation in the anti-dialectical, non-teleological Spinozian terms of potestas and potentia, constituted and constituent power, analogous to pouvoir and puissance in Foucault's work: the anti-Hegelian position in which there is no teleological prime mover to historical development such as the negation of the negation.

More systematically, the technical production of subjectivity can be characterized as differing from the postphenomenological view in the sense in which it does not remain confined to an artifact-agent relationship. As for Feenberg, the production of technically mediated subjectivity is a political affair, even if the autonomists do not use the word "mediation" and plunge the ideological back into the thoroughly materialist: the subject emerges through the constitution of a heterogeneous set of elements, through the concatenation of the material, scientific, legal, and economic mechanism at work in society. The subject is constituted by the dispositifs of power:

What I'm trying to pick out with this term is, firstly, a thoroughly heterogeneous ensemble consisting of discourses, institutions, architectural forms, regulatory decisions, laws, administrative measures, scientific statements, philosophical, moral and philanthropic propositions (...) [T] he apparatus itself is the system of relations that can be established between these elements. Secondly, what I am trying to identify in this apparatus is precisely the nature of the connection that can exist between these heterogeneous elements. (...) Thirdly, I understand by the term "apparatus" a sort of - shall we say-formation which has as its major function at a given historical moment that of responding to an urgent need. (Foucault 1980, p. 195)

That is to say, subjects are the effects of a Nietzschean play of "force upon force," of the arrangement of these forces, a strategic relation (Berardi 2005; Hardt and Negri 2000, p. 329ff; 2009, p. 126; Lazzarato 2002; Negri 2008a). ${ }^{22}$ Insofar as these strategic relations have not crystallized into complete domination, the relation between the elements can be reconfigured, in a strategic relation of resistance, in an alternative productive of subjectivity, a "government of the self and others." Dispositifs of power can be politically motivated relations of domination, but also political relations of

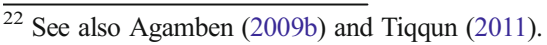


resistance. The dispositifs of the present day produces for example not merely "docile bodies" but "the precarious worker", or the "self-entrepreneur" (Foucault 2008).

\subsection{Towards an Understanding of the Technological Mediation of the Class Struggle}

Taken together, the diffusion of the class struggle, and the role of the class struggle as the propeller for capitalist development and liberation from it, offer a different perspective on how to understand the relation between power, resistance, and technological mediation from the ones developed in postphenomenology and critical theory of technology. To be sure, technological mediation is not a term often employed in the autonomist school. A leading theme, however, is the one initiated by Panzieri (1980), who developed a non-determinist understanding of technology as political weaponry ("constant capital"), developed and deployed by capital to replace, undermine, control, or in short battle its internal antagonist, the working class ("variable capital"). These weapons are not neutral, but, like for Feenberg, already imply the capitalist mode of production. Berardi (2009) follows up on these insights by arguing that neo-liberal capital ("semiocapital"), after the struggles of factory workers in the 1970s for more flexibility, has produced a new, flexible, precarious proletariat ("cognitariat") through the deployment of digital networks, underscoring the premise that capital is an inherently reactive force. Hardt and Negri, hailed as the Marx and Engels of the internet era (Žižek 2001), albeit aware that digital technologies can enhance the further surveillance and control of the multitude in a "virtual Panopticon" (2000, p. 297), also point out that "every tool is a weapon if you hold it right" (ibid., p. v), implying that the weapons of biopower can also be refitted to be wielded against capital itself. $^{23}$

The image of weaponry suggests that the technical system mediates the class struggle, or more precisely, conditions the form the class struggle takes. As conventional warfare is conditioned by the technological development of weaponry (from the trench warfare of World War I to the threat of nuclear warfare during the Cold War), so is the class struggle. For example, in the field of agriculture, the development of biotechnology and genomics has made the ownership of the genetic information contained in seed one of the most pressing issues of social struggles. Whereas farmers have used this genetic information for centuries through practical know-how, the scientific possibility of identifying knowledge-intensive genes, and their privatization through patenting, constitutes farmers as engaged in class struggle against life science companies and universities claiming ownership of plant genetic resources (Hardt and Negri 2004, pp. 112-114; Kloppenburg 2005). At the same time, the very same biotechnologies (potentially) offer farmers new ways of improving their local practices by tailoring these technologies to their own needs (Ruivenkamp 2005).

We thus believe that the phenomenon of technological mediation provides autonomist theory with both an empirical and philosophical challenge. While the bulk of autonomist theory tends to focus solely on digital technologies, Birch and Tyfield (2013) have argued for the pertinence of autonomia and its focus on labor as the source

\footnotetext{
${ }^{23}$ In their Empire trilogy, Hardt and Negri oscillate between arguing for an antagonistic "entrepreneurship of the multitude" (2009, p. 306) and the more classic dialectial "gravedigger" hypothesis, that current biopolitical production contradicts the capitalistic regime of property (ibid., pp. 131-159). These two arguments are not necessarily mutually exclusive: an entrepreneurship of the multitude performatively exhibits the contradiction in the capitalist mode of production.
} 
of all value, for the bio-economy. Especially with the emerging field of "Open Source Biotechnology" (Hope 2008), this perspective becomes ever more relevant. Moreover, while we have focused in this article on how Autonomia, through its Foucault-inspired theory of subjectivity, can be linked to the phenomenon of technical mediation through its notion of the production of subjectivity (expressed as through dispositifs), there is still need for a stronger, more encompassing theory of how we are to understand the relations between the technical system and autonomia's central category, the class struggle.

\section{Conclusion}

In this article, we have discussed and compared three positions on the intertwinement of technological mediation, power, and resistance within capitalist society through an analysis of the various ways in which they incorporate a power-perspective. First, we discussed the hermeneutic postphenomenological view developed by Verbeek, and Feenberg's dialectic critical theory, and then we brought these together for a first approximation of autonomist philosophy of technology.

Instead of invoking the metaphor of a struggle between spheres to characterize critical theory in contradistinction to co-constitutive postphenomenological mediation, it was argued that postphenomenology and critical theory are best understood as complementary. While the former excels at analyzing technical mediation at the experiential level, the latter succeeds in highlighting social biases that may elude the untrained eye. Furthermore, it was argued that Verbeek's liberaldemocratic power perspective is not radically different from Feenberg's socialism, at least in the way in which they conceptualize the category of resistance: subjects shape and transform their technically mediated subjectivity in search of the good life against the background of a web of meaning-giving power relations they neither can nor (thus) should try to fully escape, or else social groups try to mitigate the detrimental effects of technical mediations implemented by the (capitalist) system by revealing and negotiating their (thus its) ideological and cultural underpinnings. This different emphasis, which really follows from their metaphysics, converges in a conception of resistance as a form of democratization in the design of mediating technical artifacts.

In the second part, we argued that the antagonistic conceptualization of power relations developed in autonomist Marxism offers an alternative way of articulating technically mediated resistance. We did this by juxtaposing the autonomist appropriation of the political production of technological subjects through Foucauldian dispositifs of biopower with the hermeneutic and dialectical approach. By grafting this Foucauldian conception onto a Marxist framework, it was argued that antagonistic resistance should be understood as a (technically mediated) practice of challenging, displacing, and thwarting capitalist relation of production and subjectification by a subversion of the circuit of production itself. In so doing, we sketched the contours of an autonomist philosophy of technology. Technologically mediated practices such as open source and commons-based production are reshuffling such concepts as designer/user, or public/private, and they are definitely changing the very face of capitalism. Paraphrasing Deleuze, we could say 
that it is not a question of worrying or hoping for the best, but of refitting our weapons.

Open Access This article is distributed under the terms of the Creative Commons Attribution License which permits any use, distribution, and reproduction in any medium, provided the original author(s) and the source are credited.

\section{References}

Achterhuis, H. (2001). American philosophy of technology: the empirical turn. Bloomington: Indiana University Press.

Adorno, T. (1973). The jargon of authenticity. Evaston: Northwestern University Press.

Adorno, T. (2013). Against epistemology: a metacritique. Cambridge: Polity Press.

Adorno, T., \& Horkheimer, M. (2007). Dialectic of enlightenment. Stanford: Stanford University Press.

Adorno, T., Albert, H., Dahrendorf, R., Habermas, J., Pilot, H., \& Popper, K. (1976). The positivist dispute in German sociology. London: Heinemann.

Agamben, G. (2009a). The signature of all things. New York: Zone Books.

Agamben, G. (2009b). What is an apparatus? Stanford: Stanford University Press.

Allen, A. (1999). The power of feminist theory: domination, resistance, solidarity. Boulder: Westview Press.

Benkler, Y. (2006). The wealth of networks. How social production transforms markets and freedom. New Haven: Yale University Press.

Berardi, F. (2005). Biopolitics and connective mutation. Culture Machine, 7.

Berardi, F. (2009). The soul at work: from alienation to autonomy. Los Angeles: Semiotexte.

Bijker, W. E., Hughes, T. P., \& Pinch, T. (1987). The social construction of technological systems: new directions in the sociology and history of technology. Cambridge: MIT Press.

Birch, K., \& Tyfield, D. (2013). Theorizing the bioeconomy: biovalue, biocapital, bioeconomics or...what? Science, Technology, and Human Values, 38(3), 299-327.

Brey, P. (2007). The technological construction of social power. Social Epistemology, 22(1), 71-95.

Brey, P. (2010). Philosophy of technology after the empirical turn. Techné: Research in Philosophy and Technology, 14(1), 36-48.

Callinicos, A. (2001). Toni Negri in perspective (pp. 33-61). Autumn: International Socialism.

Casarino, C., \& Negri, A. (2008). In praise of the common. A conversation on philosophy and politics. Minneapolis: University of Minnesota Press.

Cleaver, H. (2000). Reading capital politically. London: AK Press.

Deleuze, G. (1986). Nietzsche and philosophy. London: Continuum.

Deleuze, G. (1995). Negotiations. New York: Columbia University Press.

Deleuze, G. (2006). Foucault. London: Continuum.

Derrida, J. (1973). Speech and phenomena and other essays. Evaston: Northwestern University Press.

Dorrestijn, S. (2012). Technical mediation and subjectivication: tracing and extending Foucault's philosophy of technology. Philosophy and Technology, 25(2), 221-241.

Dreyfus, H. L., \& Rabinow, P. (1983). Michel Foucault: beyond structuralism and hermeneutics. Chicago: Chicago University Press.

Dyer-Witheford, N. (2004). Autonomist Marxism. Santa Cruz: Treason Press.

Fay, B. (1987). Critical social science. Ithaca: Cornell University Press.

Feenberg, A. (1991). Critical theory of technology. New York: Oxford University Press.

Feenberg, A. (1995). Subversive rationalization: technology, power, and democracy. In A. Feenberg \& A. Hannay (Eds.), Technology and the politics of knowledge (pp. 3-22). Bloomington: Indiana University Press.

Feenberg, A. (1999). Questioning technology. New York: Routledge.

Feenberg, A. (2002). Transforming technology: a critical theory revisited. New York: Oxford University Press.

Feenberg, A. (2009). Peter-Paul Verbeek: review of what things do. Human Studies, 32(2), 225-228.

Feenberg, A. (2010). Between reason and experience. Essays in technology and modernity. Cambridge: MIT Press.

Feenberg, A. (2013a). The mediation is the message. Techné: Research in Philosophy and Technology, 17(1), $7-24$.

Feenberg, A. (2013b). What I said and what I should have said. Techné: Research in Philosophy and Technology, 17(1), 163-178.

Feenberg, A. (2014). The philosophy of Praxis. Marx, Lukács, and the Frankfurt School. London: Verso. 
Foucault, M. (1977). Discipline and punish. The birth of the prison. New York: Random House.

Foucault, M. (1978). The history of sexuality: vol. 1. The will to knowledge. London: Penguin.

Foucault, M. (1980). Power/knowledge. Selected interviews and other writings 1972-1977. New York: Vintage Books.

Foucault, M. (1990). The care of the self: the history of sexuality (vol. 3). London: Penguin.

Foucault, M. (1992). The use of pleasure: the history of sexuality (vol. 2). London: Penguin.

Foucault, M. (1997a). Technologies of the self. In P. Rabinow (Ed.), Ethics, subjectivity and truth: essential works of Foucault 1954-1984. Vol. I (pp. 253-280). London: Penguin.

Foucault, M. (1997b). The ethics of the concern of the self as a practice of freedom. In P. Rabinow (Ed.), Ethics, subjectivity and truth: essential works of Foucault 1954-1984. Vol. I (pp. 281-301). London: Penguin.

Foucault, M. (1997c). What is enlightenment? In P. Rabinow (Ed.), Ethics, subjectivity and truth: essential works of Foucault 1954-1984. Vol. I (pp. 303-320). London: Penguin.

Foucault, M. (1997d). Sex, power, and the politics of identity. In P. Rabinow (Ed.), Ethics, subjectivity and truth: essential works of Foucault 1954-1984. Vol. I (pp. 281-301). London: Penguin.

Foucault, M. (2002). Interview with Michel Foucault. In J. D. Faubion (Ed.), Power: essential works of Foucault 1954-1984. Vol. 3 (pp. 239-297). London: Penguin.

Foucault, M. (2003). Society must be defended. Lectures at The College de France 1975-1976. New York: Picador.

Foucault, M. (2008). The birth of biopolitics. Lectures at The College de France 1978-1979. New York: Picador.

Fraser, N. (2003). From discipline to flexibilization. Rereading Foucault in the shadow of globalization. Constellations, 10(2), 160-171.

Fraser, N. (1985). Michel Foucault: a young conservative? Ethics, 96(1), 165-184.

Gerrie, J. (2003). Was Foucault a philosopher of technology? Techné: Research in Philosophy and Technology, $7(2), 14-26$.

Gorz, A. (2010). The immaterial. London: Seagull Books.

Griffioen, A., \& Van Tuinen, S. (2009). Biomacht en Biopolitiek. De Inbedding van Foucault in het Autonoom Marxisme. Krisis, 3, 68-85.

Habermas, J. (1981). Modernity vs. postmodernity. New German Critique, 22, 3-14.

Hardt, M. (2010). The common in communism. In C. Douzinas \& S. Žižek (Eds.), The idea of communism. London: Verso.

Hardt, M., \& Negri, A. (2000). Empire. Cambridge: Harvard University Press.

Hardt, M., \& Negri, A. (2004). Multitude. War and democracy in the age of empire. London: Penguin.

Hardt, M., \& Negri, A. (2009). Commonwealth. Cambridge: Harvard University Press.

Heidegger, M. (1977). The question concerning technology and other essays. New York: Harper and Row.

Hickman, L. A. (2006). From critical theory to pragmatism: Feenberg's progress. In T. J. Veak (Ed.), Democratizing technology: Andrew Feenberg's critical theory of technology (pp. 71-84). Albany: State of New York University Press.

Hope, J. (2008). Biobazaar. The open source revolution and biotechnology. Cambridge: Harvard University Press. Horkheimer, M. (1947). Eclipse of Reason. New York: Oxford University Press

Husserl, E. (2001). Logical investigations. Volume 2. New York: Routledge.

Ihde, D. (1990). Technology and the life-world: from garden to earth. Bloomington: Indiana University Press.

Ihde, D. (1993). Postphenomenology: essays in the postmodern context. Evaston: Northwestern University Press.

Ihde, D. (2009). Postphenomenology and technoscience: The Peking Lectures. Albany: State University of New York Press.

Ihde, D., \& Selinger, E. (Eds.). (2003). Chasing technoscience: matrix for materiality. Bloomington: Indiana University Press.

Jay, M. (1984). Marxism and totality. The adventures of a concept from Lukács to Habermas. Oxford: Polity Press/Basil Blackwell.

Kaplan, D. M. (2009). What things still don’t do. Human Studies, 32(2), 229-240.

Kellner, D. (1992). Critical theory, Marxism, and modernity. Baltimore: The Johns Hopkins University Press.

Kiran, A. H., \& Verbeek, P. P. (2010). Trusting our selves to technology. Knowledge, Technology, and Policy, 23(3-4), 409-427.

Kirckpatrick, G. (2008). Technology and social power. Hants: Palgrave Macmillan.

Kloppenburg, J. (2005). First the seed: the political economy of plant biotechnology. Madison: The University of Wisconsin Press.

Latour, B. (1992). Where are the missing masses? The sociology of a few mundane artifacts. In W. E. Bijker \& J. Law (Eds.), Shaping technology/building society: studies in sociotechnical change (pp. 225-258). Cambridge: MIT Press.

Latour, B. (1993). We have never been modern. Cambridge: Harvard University Press.

Latour, B. (1994). On technical mediation. Common Knowledge, 3(2), $29-64$. 
Lazzarato, M. (2002). From biopower to biopolitics. Pli: The Warwick Journal of Philosophy, 13, 112-125. Lazzarato, M. (2004). From capital-labour to capital-life. Ephemera, 4(3), 187-208.

Lotz, C. (2011). Review of Andrew Feenberg: between reason and experience. http://marxandphilosophy.org. uk/reviewofbooks/reviews/2011/308. Accessed 1 September 2013.

Lukes, S. (2005). Power: a radical view. Second revised edition. New York: Palgrave Macmillan.

Marcuse, H. (1960). Reason and revolution: Hegel and the rise of social theory. Boston: Beacon.

Marcuse, H. (1973). Studies in critical philosophy. London: NLB.

Marcuse, H. (2002). One dimensional man: studies in the ideology of advanced industrial society. New York: Routledge.

Marx, K. (1975). Early writings. London: Penguin.

Marx, K. (1993). Grundrisse. London: Penguin.

Marx, K., \& Engels, F. (2002). The communist manifesto. London: Penguin.

Morini, C., \& Fumagalli, A. (2010). Life put to work: towards a life theory of value. Ephemera, 10(3/4), $234-252$.

Moulier Boutang, Y. (2011). Cognitive capitalism. Cambridge: Polity Press.

Nealon, J. T. (2008). Foucault beyond Foucault. Power and its intensification since 1984. Stanford: Stanford University Press.

Negri, A. (1991). The savage anomaly. The power of Spinoza's metaphysics and politics. Minneapolis: University of Minnesota Press.

Negri, A. (2008a). The labor of the multitude and the fabric of biopolitics. Mediations, 23(2), 9-26.

Negri, A. (2008b). Empire and beyond. Cambridge: Polity Press.

Newfield, C. (2013). Corporate open source. Intellectual property and the struggle over value. Radical Philosophy, 181.

Noble, D. (1984). Forces of production; a social history of industrial automation. New York: Knopf.

Panzieri, R. (1980). The capitalist use of machinery: Marx versus the objectivists. In P. Slater (Ed.), Outlines of a critique of technology (pp. 44-69). Highlands: Humanities.

Rabinow, P., \& Rose, N. (2006). Biopower today. Biosocieties, 1, 195-217.

Ruivenkamp, G. (2005). Tailor-made biotechnologies: between bio-power and sub-politics. Tailoring Biotechnologies, 1(1), 11-33.

Sawicki, J. (2003). Heidegger and Foucault: escaping technological Nihilism. In A. Milchman \& A. Rosenberg (Eds.), Foucault and Heidegger: critical encounters (pp. 55-73). Minneapolis: University of Minnesota Press.

Söderberg, J. (2007). Hacking capitalism. The free and open source software movement. London: Routledge.

Sprague, J. (2011). Empire, global capitalism, and theory: reconsidering Hardt and Negri. Current Perspectives in Social Theory, 29, 187-207.

Stallman, R. M. (2002). Free software, free society. Selected essays of Richard M. Stallman. Boston: Free Software Foundation.

Stiegler, B. (1998). Technics and time, 1. The fault of Epimetheus. Stanford: Stanford University Press.

Thompson, P. (2005). Foundation and empire: a critique of Hardt and Negri. Capital and Class, 29(2), 73-98.

Tiqqun, A. (2011). This is not a program. Los Angeles: Semiotexte.

Van Den Eede, Y. (2011). In between us: on the transparency and opacity of technological mediation. Foundations of Science, 16(2/3), 139-159.

Verbeek, P. P. (2005). What things do: philosophical reflections on technology, agency, and design. University Park: Pennsylvania University State Press.

Verbeek, P. P. (2011). Moralizing technology: understanding and designing the morality of things. Chicago: Chicago University Press.

Verbeek, P. P. (2012). Expanding mediation theory. Foundations of Science, 17(4), 391-395.

Verbeek, P. P. (2013). Resistance is futile. Techné: Research in Philosophy and Technology, 17(1), $72-92$.

Virno, P. (2004). A grammar of the multitude. Los Angeles: Semiotexte.

Winner, L. (1986). The whale and the reactor. A search for limits in an age of high technology. Chicago: Chicago University Press.

Winner, L. (1993). Upon opening the blackbox and finding it empty: social constructivism and the philosophy of technology. Science, Technology, and Human Values, 18(3), 362-378.

Wright, S. (2002). Storming heaven. Class composition and struggle in Italian autonomist Marxism. London: Pluto Press.

Žižek, S. (2001). Have Michael Hardt and Antonio Negri rewritten the communist manifesto for the twentyfirst century? Rethinking Marxism. A Journal of Economics, Culture, and Society, 13(3/4), 190-198. 